\title{
Archæological Investigations in the Libyan Desert
}

$\mathrm{T}$

HE Libyan Desert is a never-failing source of archæological material of interest and often of considerable importance. Further evidence in support of this was afforded by the account given by $\mathrm{Mr}$. W. B. Kennedy Shaw before the Royal Geographical Society on January 6 of an expedition in 1935 of which he was leader. The main objective of the expedition was the further exploration of the Wadi Hawa, which west of long. $24^{\circ}$ forms the boundary between French Equatorial Africa and the AngloEgyptian Sudan. East of that meridian, the Wadi has been visited only by four expeditions since 1923 , and is little known, a section of fifty miles being unsurveyed and the extreme eastern end unexplored until the present occasion.

Between January 14 and April 9, 1935, the party covered 6,300 miles, of which half was through unexplored country. Before setting out for the main objective, a visit was paid to the Gilf Kebir plateau and its recently discovered wadis, with the view of searching for rock paintings additional to those already reported. Small caves or rock shelters on the neck of a re-entrant valley provided a series of twenty-five in red and white, showing human figures and animals which included Bos africanus, the cattle of Egyptian Predynastic and Old Kingdom times afterwards superseded by $B$. brachyceros. Their collars, or halters, spotted coats and prominent udders show that the domesticated animals were intended. One painting shows a woman seated inside a cave or hut. It is stated that the Abbé Breuil, who has examined the expedition's copies, dates these paintings as Predynastic of about 50004000 B.c. The series, of which full details will be published later, should prove a valuable addition to the examples of prehistoric art already known from the Libyan Desert. A solitary cairn burial in 'Grassy Valley' (which lies somewhere about 100 miles southeast of 'Uweinat) yielded a crouched skeleton with carnelian beads and a pot closely paralleled in the Predynastic period.

In the Wadi Hawa some valuable work of exploration was carried out with which it is not proposed to deal specifically here, excopt to say that the whole of the Wadi from long. $24^{\circ}$ eastward was traversed and surveyed, and observations taken of the animal and vegetable life. The archæological investigations covered a number of ancient sites, which occur along the Wadi. On a hill on the north bank were some hundreds of stone grave cairns. Of these, two were opened and found each to contain a contracted burial but without associated objects. At one large site farther to the east was found the evidence of what had clearly been an important settlement. The ground was covered with sherds, ashes and burnt bones with polished diorite axes, ostrich-shell beads, querns, grinders, etc. Here burials are unmarked by cairns or otherwise.

Two or three skeletons were excavated. One had a necklace of five turquoise beads, dated tentatively as Old Kingdom, and at its waist were many coils of ostrich-shell beads. Farther east near Jobel Rahib cairn burials re-appear. In one of these, two halves of a cow's jaw had been buried alongside the body. What was perhaps the most interesting and significant discovery, however, was made in a depression lying between Merga and Burg et Tuyur, where a number of old water pans indicates the attraction for an early population, of which evidence was seen in fragments of pottery and implements. The skull of a skeleton obtained here has been pronounced by Dr. Cave of the Royal College of surgeons to agree strikingly with the Predynastic type. Though there were no objects associated with this burial, nearby were animal bones, sherds, polished stone axes, ostrichshell fragments, otc., of a kind similar to those found in Wadi Hawa. Hitherto archæological material from Hawa has been assigned to Meroitic times. Here, however, is evidence of a considerable and much earlier population, which the character of their artefacts shows to have followed an agricultural and pastoral mode of life. These pursuits for such a number would have been impossible either to-day or in Meroitic times, and evidently point to conditions more favourable some four to five thousand years the latter.

\section{Passenger Transport in London and Berlin}

$I^{N}$ a paper read to the Royal Society of Arts on December 11, Mr. Frank Pick discussed the organisation of London transport with special reference to the London Passenger Transport Board. $\mathrm{He}$ pointed out that progress in conceiving and organising London has been unequal and unbalanced. The L.P.T.B. enjoys at present a certain uniqueness of character which makes its study useful and advantageous. There is a drawback in the fact that the suburban services of the main line railways, representing 273 million car miles, are still dispersed in the hands of four amalgamated companies. These services represented in car miles 34 per cent of the whole, or in passengers 13 per cent of the whole.
There is a standing joint committee to settle disputes, but this is not the same as the welding of those interests into one. The electrification of the Southern Railway and the failure to electrify the railways north of the Thames have led to the growth of London in the south, and have diverted the population in that direction.

Unluckily, traffic considerations are partially subordinated to other considerations still retaining elements of competition. Local authorities vie with one another in seeking expansion. Housing programmes have a tendency to settle and concentrate in unexpected areas. In particular, a vacant piece of land, vacant because the transport facilities are 